\title{
Povezanost količine i distribucije masnog tkiva s tumorskim karakteristikama invazivnog karcinoma dojke u postmenopauzalnih žena
}

\section{Connection between invasive breast cancer characteristics and adipose tissue quantity and distribution in postmenopausal women}

\author{
Marija Krpina ${ }^{1 *}$, Lucija Knez ${ }^{1}$, Andrej Belančić ${ }^{1}$, Paula Georgev ${ }^{1}$, Martina Demaria ${ }^{1}$, \\ Manuela Avirović2 ${ }^{2}$ Marina Kosmat ${ }^{3}$, Franjo Lovasićc ${ }^{3}$ Elvira Mustać ${ }^{2}$
}

\begin{abstract}
Sažetak. Cilj: Procijeniti utječu li količina i distribucija masnog tkiva na karakteristike i agresivnost karcinoma dojke u postmenopauzalnih žena. Ispitanici i metode: Istraživanje je obuhvatilo 70 postmenopauzalnih žena s invazivnim karcinomom dojke. Pacijenticama su u trenutku postavljanja dijagnoze uzete antropometrijske mjere (tjelesna visina (TV), tjelesna masa (TM), opseg struka (OS), opseg bokova (OB) te izračunati pridruženi indeks tjelesne mase (ITM) i waist hip ratio (WHR). Iz patohistoloških nalaza prikupili su se podaci o karakteristikama tumora: veličina, histološki gradus, ekspresija estrogenskih (ER) i progesteronskih receptora (PR), HER2 i Ki67 te imunohistokemijski tip tumora. Rezultati: Pacijentice su bile prosječne dobi 65 godina $(42-86)$, TV 164,8 $\pm 7,0 \mathrm{~cm}, \mathrm{TM} 75,6 \pm 14,5 \mathrm{~kg}$, ITM $27,9 \pm 5,3 \mathrm{~kg} / \mathrm{m}^{2}$, OS $90,5 \pm 12,4 \mathrm{~cm}$, OB $107,6 \pm 11,7 \mathrm{~cm}$, WHR 0,84 $\pm 0,07$. Raspodjelom u skupine $\mathrm{s}$ obzirom na pridruženi ITM uz pomoć hi-kvadrat testa dokazala se statistički značajno veća pojavnost estrogen pozitivnih ( $n=41,91,1 \%$ vs $n=18,72,0 \% ; P=0,037$ ), progesteron pozitivnih ( $\mathrm{n}=38,84,4 \%$ vs $\mathrm{n}=11,44,0 \% ; P<0,001$ ) te luminal A karcinoma dojke $(n=15,33,3 \%$ vs $n=2,8,0 \% ; P=0,019)$ u skupini prekomjerno uhranjenih (ITM $>25$ $\mathrm{kg} / \mathrm{m}^{2}$ ). Nadalje, raspodjelom prema OS-u dokazala se statistički značajno češća pojavnost estrogen pozitivnih ( $n=52,88,1 \%$ vs $n=7,63,6 \% ; P=0,042)$, progesteron pozitivnih $(n=45$, $76,3 \%$ vs $n=4,36,4 \% ; P=0,008$ ) i luminal A karcinoma dojke ( $n=17,28,8 \%$ vs $n=0,0 \% ; P$ $=0,042)$ te statistički značajno rjeđa pojavnost trostruko negativnih karcinoma dojke $(n=1$, $1,7 \%$ vs $n=2,18,2 \% ; P=0,014)$ u skupini s OS $>80 \mathrm{~cm}$. Zaključci: $S$ količinom masnog tkiva raste stupanj ekspresije progesterona i estrogena. Potonje bi se moglo objasniti porastom ekspresije aromataze u masnom tkivu.
\end{abstract}

Ključne riječi: aromataza; debljina; estrogen; karcinom dojke; progesteron
Napomena: Rad je prezentiran na 7. hrvatskom kongresu o debljini s međunarodnim sudjelovanjem (26. - 29. travnja 2018., Opatija; organizator: Hrvatsko društvo za debljinu) te prema Uredništvu časopisa Medicina Fluminensis odabran kao najbolje kongresno priopćenje.
${ }^{1}$ Sveučilište u Rijeci, Medicinski fakultet, Rijeka

${ }^{2}$ Zavod za patologiju, Sveučilište u Rijeci, Medicinski fakultet, Rijeka

${ }^{3}$ Zavod za opću kirurgiju, Klinika za kirurgiju, Klinički bolnički centar Rijeka, Rijeka

*Dopisni autor:

Marija Krpina

Sveučilište u Rijeci, Medicinski fakultet Braće Branchetta 20, 51000 Rijeka e-mail: mkrpina1102@gmail.com

http://hrcak.srce.hr/medicina 
72.0\%; $P=0.037)$, progesterone positive $(n=38,84.4 \%$ vs $n=11,44.0 \% ; P<0.001)$ and luminal $A$ breast cancers $(n=15$, $33.3 \%$ vs $n=2,8.0 \% ; P=0.019$ ) were significantly more frequent in $\mathrm{BMI}>25 \mathrm{~kg} / \mathrm{m}^{2}$ group. Moreover, estrogen positive $(n=52$, $88.1 \%$ vs $n=7,63.6 \% ; P=0.042)$, progesterone positive $(n=45$, $76.3 \%$ vs $n=4,36.4 \% ; P=0.008$ ) and luminal $A$ breast cancers ( $n=17,28.8 \%$ vs $n=0.0 ; P=0.042$ ) were significantly more frequent in patients with $W C>80 \mathrm{~cm}$, while there was also a significantly lower number of triple negative breast cancers in the latter group $(n=1,1.7 \%$ vs $n=2,18.2 \% ; P=0.014)$. Conclusions: PR and ER expression positively correlates with adipose tissue quantity, most probably due to higher expression of aromatase.

Key words: aromatase; breast cancer; estrogen; obesity; progesterone

Poznato je da je debljina rizični čimbenik za razvoj karcinoma dojke u postmenopauzalnih žena, no još uvijek nije razjašnjeno utječu li količina i distribucija masnog tkiva na karakteristike tumora i njegovu agresivnost. Cilj ovog istraživanja je procijeniti tumorske karakteristike invazivnog karcinoma dojke ovisno o pridruženim antropometrijskim mjerama oboljelih postmenopauzalnih žena.

\section{UVOD}

Karcinom dojke je zloćudni tumor dojke koji nastaje proliferacijom epitela terminalnih kanalića ili dukto-lobularnih jedinica. Riječ je o najčešćoj vrsti karcinoma u ženske populacije s oko 1,67 milijuna novodijagnosticiranih slučajeva i 522 tisuće smrtnih ishoda godišnje ${ }^{1}$. Posebice zabrinjava podatak da je incidencija karcinoma dojke u konstantnom porastu za oko 3,1 \% godišnje ${ }^{2}$. Za usporedbu, prema podacima Registra za rak Hrvatskog zavoda za javno zdravstvo, incidencija karcinoma dojke u Republici Hrvatskoj za 2014. godinu iznosila je $119,2 / 100000$, a stopa mortaliteta 48,3/100 000, čime se Republika Hrvatska nalazi iznad europskog prosjeka (incidencija u Europi 89,4/100 000; mortalitet u Europi 28,7/100 $000)^{3}$. Oko $67 \%$ svih slučajeva karcinoma dojke javlja se u postmenopauzalnih žena, a značajnu razliku između premenopauzalne i postmenopauzalne incidencije karcinoma dojke najbolje predočuje usporedba dobno standardiziranih stopa incidencije $(12,8-29,4 / 100000$ vs 65,4 $307,6 / 100000)^{4,5}$.
Rizične faktore za razvoj karcinoma dojke možemo podijeliti na nemodificirajuće; spol, dob, genetska predispozicija, pozitivna obiteljska anamneza, rana menarha, kasna menopauza, prethodna izloženost dojke zračenju, gusti parenhim dojke, terapija dietilstilbestrolom, i na modificirajuće; kasna dob prve trudnoće, nuliparitet, inducirani pobačaj, nedojenje, hormonska nadomjesna terapija, konzumacija alkohola, nedostatna fizička aktivnost te preuhranjenost i debljina ${ }^{6}$. Debljina (indeks tjelesne mase - ITM $\geq 30 \mathrm{~kg} / \mathrm{m}^{2}$ ) i preuhranjenost (ITM $25-30 \mathrm{~kg} / \mathrm{m}^{2}$ ) prema Svjetskoj zdravstvenoj organizaciji (SZO) definiraju se kao stanja prekomjernog nakupljanja masnog tkiva s negativnim posljedicama na zdravlje. $\mathrm{S}$ obzirom na distribuciju masnog tkiva razlikujemo abdominalni/visceralni i potkožni/periferni tip debljine, a za njihovu procjenu u praksi najčešće se koriste opseg struka (OS) i waist hip ratio (WHR). Sukladno podacima epidemioloških studija, prema kojima je 1,9 milijardi odraslih starijih od 18 godina danas pretilo ili preuhranjeno, debljina predstavlja rastući javnozdravstveni problem pandemijskih razmjera. Aktualni podaci SZO-a pokazuju da se prevalencija debljine skoro pa utrostručila u odnosu na brojke iz 1975. godine te da na svijetu u ovom trenutku živi oko 650 milijuna pretilih odraslih osoba. Nadalje, prema podacima Europske zdravstvene ankete, koja se provodila 2014. godine na razini zemalja članica Europske unije, pretilo je 15,9\% europskog stanovništva, a 35,7\% je preuhranjeno. Stratifikacijom tako prikupljenih podataka prema spolu dobivena je brojka od 15,7\% pretilih te $28,4 \%$ preuhranjenih žena, što je približno epidemiološkim podacima na razini Republike Hrvatske, gdje je oko 16,8 \% žena pretilo, odnosno 31,4 \% preuhranjeno ${ }^{7}$. Preuhranjenost i debljina nažalost ne dolaze sami za sebe, već su udružene sa širokim spektrom potencijalnih komplikacija. Potonje možemo najpreciznije podijeliti u četiri velike skupine - metaboličke, mehaničke, psihosocijalne komplikacije te malignitete, među koje ubrajamo i invazivni karcinom dojke. S obzirom na to da je debljina rastući javnozdravstveni problem pandemijskih razmjera, s njome je u konstantnom porastu i incidencija invazivnog karcinoma dojke. Brojna su istraživanja dokazala jasnu povezanost između preuhranjenosti/debljine i pojavnosti in- 
vazivnog karcinoma dojke u postmenopauzalnih žena. Sukladno rezultatima metaanalize Anne Bergström i suradnika, koja je provedena 2001. godine, poznato je da se oko $8,5 \%$ slučajeva invazivnog karcinoma dojke u žena starijih od 50 godina te oko 6,6 \% slučajeva invazivnog karcinoma dojke, općenito za sve dobne skupine, može izričito pripisati preuhranjenosti i debljini. Nadalje, zanimljiv je i podatak da se s porastom ITM-a, za svakih $1 \mathrm{~kg} / \mathrm{m}^{2}$ iznad optimalne granice, povećava i rizik od nastanka karcinoma dojke u iznosu od dodatnih $2 \%^{8}$.

Osim konkretne vrijednosti ITM-a, značajan utjecaj na sveukupni rizik ima i distribucija masnog tkiva, odnosno odsutnost/prisutnost abdominalnog obrasca debljine. Točnije, u postmenopauzalnih žena s optimalnim opsegom struka rizik za razvoj karcinoma dojke manji je za $39 \%$, dok se u slučaju optimalne vrijednosti WHR rizik smanjuje za $24 \%{ }^{9}$.

Valja naglasiti da je poznato da je debljina rizični čimbenik za razvoj karcinoma dojke u postmenopauzalnih žena, no još uvijek nije razjašnjeno utječu li količina i distribucija masnog tkiva na karakteristike tumora i njegovu agresivnost. S obzirom na navedeno, cilj ovog istraživanja je procijeniti tumorske karakteristike invazivnog karcinoma dojke ovisno o pridruženim antropometrijskim mjerama oboljelih postmenopauzalnih žena.

\section{ISPITANICI I METODE}

Istraživanje se provodilo prospektivno u periodu od travnja do prosinca 2017. godine, a obuhvatilo je 70 postmenopauzalnih žena s invazivnim karcinomom dojke. Pacijenticama su se u trenutku postavljanja dijagnoze na Zavodu za opću kirurgiju Klinike za kirurgiju Kliničkog bolničkog centra Rijeka uzimale antropometrijske mjere (tjelesna visina (TV), tjelesna masa (TM), opseg struka (OS), opseg bokova (OB). Opseg struka mjerio se na polovini udaljenosti između donjeg rebrenog luka i cristae iliacae bočno, na mjestu gdje su najbliži, u ekspiriju. Opseg bokova mjerio se na njegovu najširem dijelu - oko stražnjice u visini trohantera. ITM je dobiven računski tako da se tjelesna masa pacijentica u kilogramima podijelila s kvadratom visine u metrima, dok je WHR izračunat
Tablica 1. Klasifikacija TNM stadija karcinoma dojke

\begin{tabular}{|c|c|c|c|}
\hline $\begin{array}{c}\text { TNM stadij } \\
\text { karcinoma dojke }\end{array}$ & $\mathbf{T}$ & $\mathbf{N}$ & $\mathbf{M}$ \\
\hline 0 & $\mathrm{~T}_{\text {is }}$ & $\mathrm{N}_{0}$ & $\mathrm{M}_{0}$ \\
\hline 1 & $\mathrm{~T}_{1}$ & $\mathrm{~N}_{0}$ & $M_{0}$ \\
\hline $2 A$ & $\begin{array}{l}\mathrm{T}_{0} \\
\mathrm{~T}_{1} \\
\mathrm{~T}_{2}\end{array}$ & $\begin{array}{l}\mathrm{N}_{1} \\
\mathrm{~N}_{1} \\
\mathrm{~N}_{0}\end{array}$ & $\begin{array}{l}M_{0} \\
M_{0} \\
M_{0}\end{array}$ \\
\hline $2 B$ & $\begin{array}{l}\mathrm{T}_{2} \\
\mathrm{~T}_{3}\end{array}$ & $\begin{array}{l}\mathrm{N}_{1} \\
\mathrm{~N}_{0}\end{array}$ & $\begin{array}{l}M_{0} \\
M_{0}\end{array}$ \\
\hline $3 A$ & $\begin{array}{l}\mathrm{T}_{0} \\
\mathrm{~T}_{1} \\
\mathrm{~T}_{2} \\
\mathrm{~T}_{3} \\
\mathrm{~T}_{3}\end{array}$ & $\begin{array}{l}\mathrm{N}_{2} \\
\mathrm{~N}_{2} \\
\mathrm{~N}_{2} \\
\mathrm{~N}_{1} \\
\mathrm{~N}_{2}\end{array}$ & $\begin{array}{l}\mathrm{M}_{0} \\
\mathrm{M}_{0} \\
\mathrm{M}_{0} \\
\mathrm{M}_{0} \\
\mathrm{M}_{0}\end{array}$ \\
\hline 3B & $\begin{array}{l}\mathrm{T}_{4} \\
\mathrm{~T}_{4} \\
\mathrm{~T}_{4}\end{array}$ & $\begin{array}{l}\mathrm{N}_{0} \\
\mathrm{~N}_{1} \\
\mathrm{~N}_{2}\end{array}$ & $\begin{array}{l}M_{0} \\
M_{0} \\
M_{0}\end{array}$ \\
\hline $3 C$ & $\mathrm{~T}_{\mathrm{x}}$ & $\mathrm{N}_{3}$ & $M_{0}$ \\
\hline 4 & $\mathrm{~T}_{\mathrm{x}}$ & $\mathrm{N}_{\mathrm{x}}$ & $M_{1}$ \\
\hline
\end{tabular}

kao omjer opsega struka i opsega bokova. Iz baze podataka Zavoda za patologiju Medicinskog fakulteta prikupili su se podaci o karakteristikama tumora: veličina, histološki gradus (tablica 1), ekspresija estrogenskih (ER) i progesteronskih receptora (PR), HER2 i Ki67 te se odredio imunohistokemijski tip tumora sukladno aktualnim St. Gallen smjernicama (tablica 2). Kako bi se istražio učinak količine i distribucije masnog tkiva na tumorske karakteristike invazivnog karcinoma dojke pacijentice su podijeljene u skupine s obzirom na vrijednost pridruženog ITM-a i WHR-a. Sukladno kriterijima SZO-a, kao cut-off za raspodjelu prema ITM-u uzela se vrijednost od $25 \mathrm{~kg} / \mathrm{m}^{2}$, čime su prvom skupinom obuhvaćene optimalno uhranjene (ITM $18,5-25 \mathrm{~kg} / \mathrm{m}^{2}$ ) i pothranjene pacijentice (ITM < 18,5 kg/m²), dok su se drugom skupinom obuhvatile one preuhranjene (ITM 25$\left.30 \mathrm{~kg} / \mathrm{m}^{2}\right)$ i pretile (ITM > $\left.30 \mathrm{~kg} / \mathrm{m}^{2}\right)$. Kao cut-off vrijednost za raspodjelu u skupine prema opsegu struka, sukladno kriterijima Međunarodne dijabetološke federacije (IDF), uzela se vrijednost od $80 \mathrm{~cm}$, dok se za WHR uzela vrijednost 0,85 , kako nalaže SZO. 
Tablica 2. Određivanje imunohistokemijskog surogata podtipa karcinoma dojke prema St. Gallen preporukama

\begin{tabular}{|c|c|c|}
\hline \multicolumn{2}{|l|}{ Luminal A } & $\begin{array}{l}\text { - ER pozitivan } \\
\text { - PR pozitivan } \\
\text { - Niska ekspresija Ki67 ( }<20 \%)\end{array}$ \\
\hline \multirow[b]{2}{*}{ Luminal B } & HER2 negativni & $\begin{array}{l}\text { - ER pozitivan } \\
\text { - HER2 negativan } \\
\text { - PR pozitivan i/ili visoka ekspresija Ki67 ( } \geq 20 \%)\end{array}$ \\
\hline & HER2 pozitivni & $\begin{array}{l}\text { - ER pozitivan } \\
\text { - HER2 pozitivan } \\
\text { - PR pozitivan ili PR negativan } \\
\text { - Niska ekspresija Ki67 ( }<20 \% \text { ) ili visoka ekspresija Ki67 ( } \geq 20 \%)\end{array}$ \\
\hline \multicolumn{2}{|c|}{ HER2 pozitivni } & $\begin{array}{l}\text { - HER2 pozitivan } \\
\text { - ER negativan } \\
\text { - PR negativan }\end{array}$ \\
\hline \multicolumn{2}{|c|}{ Trostruko negativni } & $\begin{array}{l}\text { - ER negativan } \\
\text { - PR negativan } \\
\text { - HER2 negativan }\end{array}$ \\
\hline
\end{tabular}

\section{Statistička obrada podataka}

Za statističku obradu prikazane su apsolutne i relativne frekvencije, mjere središnjice i raspršenja, Studentov t-test za nezavisne uzorke, hi-kvadrat test i Pearsonov koeficijent korelacije. Korišteni su programi MedCalc v12.1.3 (MedCalc Software bvba, Ostend, Belgium) i Microsoft Excel (Microsoft Office). Za testiranje normalnosti raspodjele korišten je Kolmogorov-Smirnovljev test. Razina statističke značajnosti procijenjena je na $P<0,05$.

\section{REZULTATI}

Medijan dobi pacijentica uključenih u studiju iznosio je 65 godina $(42-86)$. Pacijentice su imale prosječan TV 164,8 $\pm 7,0 \mathrm{~cm}$, TM 75,6 $\pm 14,5 \mathrm{~kg}$, ITM $27,9 \pm 5,3 \mathrm{~kg} / \mathrm{m}^{2}$, OS 90,5 $\pm 12,4 \mathrm{~cm}$, OB 107,6 \pm $11,7 \mathrm{~cm}$, WHR 0,84 $\pm 0,07$ (tablica 3). Raspodjelom u skupine s obzirom na pridruženi ITM uz pomoć hi-kvadrat testa dokazala se statistički značajno veća pojavnost estrogen pozitivnih ( $n=41,91,1 \%$ vs $\mathrm{n}=18,72,0 \% ; P=0,037)$, progesteron pozitivnih ( $n=38,84,4 \%$ vs $n=11,44,0 \% ; P<0,001$ ) te luminal A karcinoma dojke ( $n=15,33,3 \%$ vs $n=2$, $8,0 \% ; P=0,019)$ u skupini prekomjerno uhranjenih $\left(\right.$ ITM $>25 \mathrm{~kg} / \mathrm{m}^{2}$ ) pacijentica (tablica 4). Nadalje, raspodjelom prema pridruženom OS-u dokazala se statistički značajno češća pojavnost estrogen pozitivnih ( $\mathrm{n}=52,88,1 \%$ vs $\mathrm{n}=7,63,6 \%$; $P=$ 0,042 ), progesteron pozitivnih ( $n=45,76,3 \%$ vs $n$ $=4,36,4 \% ; P=0,008$ ) i luminal A karcinoma dojke ( $n=17,28,8 \%$ vs $n=0,0 \% ; P=0,042$ ) te statistički značajno rjeđa pojavnost trostruko negativnih karcinoma dojke ( $\mathrm{n}=1,1,7 \%$ vs $\mathrm{n}=2,18,2 \%$; $P=$ 0,014 ) u skupini s OS $>80 \mathrm{~cm}$ (tablica 5). Podjelom prema WHR-u nije pronađena statistički značajna razlika u tumorskim karakteristikama (tablica 6). Korelacije između antropometrijskih parametara u odnosu na veličinu tumora, postotak ekspresije estrogenskih i progesteronskih receptora te postotak Ki67 ekspresije prikazani su u tablici 7.

Tablica 3. Karakteristike ispitivane skupine postmenopauzalnih žena s invazivnim karcinomom dojke $(n=70)$. Podaci su izraženi u obliku apsolutnih i relativnih frekvencija, aritmetičke sredine \pm standardne devijacije, odnosno *medijana i raspona.

\begin{tabular}{|l|c|}
\hline *Dob / godina & $* 65(42-86)$ \\
\hline Visina / cm & $164,8 \pm 7,0$ \\
\hline Težina / kg & $75,6 \pm 14,5$ \\
\hline Indeks tjelesne mase / kg/m² & $27,9 \pm 5,3$ \\
\hline Opseg struka / cm & $90,5 \pm 12,4$ \\
\hline Opseg bokova / cm & $107,6 \pm 11,7$ \\
\hline Waist hip ratio & $0,84 \pm 0,07$ \\
\hline
\end{tabular}


Tablica 4. Karakteristike tumora s obzirom na raspodjelu u skupine prema indeksu tjelesne mase (ITM). Za procjenu statističke značajnosti $(P<0,05)$ korišteni su Studentov t-test za nezavisne uzorke i hi-kvadrat test.

\begin{tabular}{|c|c|c|c|c|c|}
\hline \multicolumn{3}{|c|}{ Parametar } & $\begin{array}{c}\text { Skupina } 1(\text { ITM < 25), } \\
n=25(35,7 \%)\end{array}$ & $\begin{array}{c}\text { Skupina } 2(\text { ITM > 25), } \\
n=45(64,3 \%)\end{array}$ & $P$ vrijednost \\
\hline \multicolumn{3}{|c|}{ Dob/Mdn (min-maks) (godina) } & $63(42-86)$ & $68(51-84)$ & 0,065 \\
\hline \multicolumn{3}{|c|}{ Veličina tumora / X \pm SD (cm) } & $1,84 \pm 1,06$ & $2,40 \pm 2,18$ & 0,232 \\
\hline \multirow{3}{*}{\multicolumn{2}{|c|}{ Gradus tumora / n (\%) }} & 1 & $4(16,0)$ & $12(26,7)$ & 0,311 \\
\hline & & 2 & $18(72,0)$ & $29(64,4)$ & 0,520 \\
\hline & & 3 & $3(12,0)$ & $4(8,9)$ & 0,681 \\
\hline \multirow{4}{*}{\multicolumn{2}{|c|}{ Tip tumora-IHC / n (\%) }} & 1 & $2(8,0)$ & $15(33,3)$ & $\underline{0,019}$ \\
\hline & & 2 & $16(64,0)$ & $26(57,8)$ & 0,614 \\
\hline & & 3 & $5(20,0)$ & $3(6,7)$ & 0,096 \\
\hline & & 4 & $2(8,0)$ & $1(2,2)$ & 0,254 \\
\hline \multirow{2}{*}{\multicolumn{2}{|c|}{ Estrogen / n (\%) }} & $+(>1 \%)$ & $18(72,0)$ & $41(91,1)$ & \multirow{2}{*}{$\underline{0,037}$} \\
\hline & & $-(<1 \%)$ & $7(28,0)$ & $4(8,9)$ & \\
\hline \multirow{2}{*}{\multicolumn{2}{|c|}{ Progesteron / n (\%) }} & $+(>1 \%)$ & $11(44,0)$ & $38(84,4)$ & \multirow{2}{*}{$\leq 0,001$} \\
\hline & & $-(<1 \%)$ & $14(56,0)$ & $7(15,6)$ & \\
\hline \multirow{2}{*}{ HER2 / n (\%) } & & + & $8(32,0)$ & $7(15,6)$ & \multirow{2}{*}{0,112} \\
\hline & & - & $17(68,0)$ & $38(84,4)$ & \\
\hline \multirow{2}{*}{$\begin{array}{l}\text { Ki67 } \\
\text { ekspresija / n (\%) }\end{array}$} & & $(\geq 20 \%)$ & $12(48,0)$ & $22(48,9)$ & \multirow{2}{*}{0,943} \\
\hline & & (< $20 \%)$ & $13(52,0)$ & $23(51,1)$ & \\
\hline
\end{tabular}

Objašnjenje - tip tumora: 1 - luminalni A, 2 - luminalni B, 3-HER2+, 4 - trostruko negativni.

Tablica 5. Karakteristike tumora s obzirom na raspodjelu u skupine prema opsegu struka (OS). Za procjenu statističke značajnosti $(P<0,05)$ korišteni su Studentov t-test za nezavisne uzorke i hi-kvadrat test.

\begin{tabular}{|c|c|c|c|c|}
\hline \multicolumn{2}{|c|}{ Parametar } & $\begin{array}{c}\text { Skupina } 1(\mathrm{OS}<80 \mathrm{~cm}) \\
n=11(15,7 \%)\end{array}$ & $\begin{array}{c}\text { Skupina } 2(\text { OS }>80 \mathrm{~cm}) \\
n=59(84,3 \%)\end{array}$ & $P$ vrijednost \\
\hline \multicolumn{2}{|c|}{ Dob/Mdn (min-maks) (godina) } & $58(42-75)$ & $66(51-86)$ & $\underline{0,015}$ \\
\hline \multicolumn{2}{|c|}{ Veličina tumora / $\mathrm{X} \pm \mathrm{SD}(\mathrm{cm})$} & $1,95 \pm 1,29$ & $2,23 \pm 1,95$ & 0,649 \\
\hline \multirow{3}{*}{ Gradus tumora / n (\%) } & 1 & $2(18,2)$ & $14(23,7)$ & 0,692 \\
\hline & 2 & $7(63,6)$ & $40(67,8)$ & 0,787 \\
\hline & 3 & $2(18,2)$ & $5(8,5)$ & 0,329 \\
\hline \multirow{4}{*}{ Tip tumora - IHC / n (\%) } & 1 & $0(0)$ & $17(28,8)$ & $\underline{0,042}$ \\
\hline & 2 & $7(63,6)$ & $35(59,3)$ & 0,791 \\
\hline & 3 & $2(18,2)$ & $6(10,2)$ & 0,448 \\
\hline & 4 & $2(18,2)$ & $1(1,7)$ & $\underline{0,014}$ \\
\hline \multirow{2}{*}{ Estrogen / n (\%) } & $+(>1 \%)$ & $7(63,6)$ & $52(88,1)$ & \multirow{2}{*}{$\underline{0,042}$} \\
\hline & $-(<1 \%)$ & $4(36,4)$ & $7(11,9)$ & \\
\hline \multirow{2}{*}{ Progesteron / n (\%) } & $+(>1 \%)$ & $4(36,4)$ & $45(76,3)$ & \multirow{2}{*}{$\underline{0,008}$} \\
\hline & $-(<1 \%)$ & $7(63,6)$ & $14(23,7)$ & \\
\hline \multirow{2}{*}{ HER2 / n (\%) } & + & $4(36,4)$ & $11(18,6)$ & \multirow{2}{*}{0,189} \\
\hline & - & $7(63,6)$ & $48(81,4)$ & \\
\hline \multirow{2}{*}{$\begin{array}{l}\text { Ki67 } \\
\text { ekspresija / n (\%) }\end{array}$} & $(\geq 20 \%)$ & $7(63,6)$ & $27(45,8)$ & \multirow{2}{*}{0,282} \\
\hline & $(<20 \%)$ & $4(36,4)$ & $32(54,2)$ & \\
\hline
\end{tabular}

Objašnjenje - tip tumora: 1 - luminalni A, 2 - luminalni B, 3 - HER2+, 4 - trostruko negativni. 
Tablica 6. Karakteristike tumora s obzirom na raspodjelu u skupine prema waist hip ratio-WHR. Za procjenu statističke značajnosti $(P<0,05)$ korišteni su Studentov t-test za nezavisne uzorke i hi-kvadrat test.

\begin{tabular}{|c|c|c|c|c|c|}
\hline \multicolumn{3}{|c|}{ Parametar } & $\begin{array}{c}\text { Skupina } 1(\text { WHR }<0,85), \\
n=35(50 \%)\end{array}$ & $\begin{array}{c}\text { Skupina } 2(\text { WHR > 0,85), } \\
n=35(50 \%)\end{array}$ & $P$ vrijednost \\
\hline \multicolumn{3}{|c|}{ Dob/Mdn (min-maks) (godina) } & $65(42-81)$ & $66(52-86)$ & 0,682 \\
\hline \multicolumn{3}{|c|}{ Veličina tumora / X \pm SD (cm) } & $1,93 \pm 1,24$ & $2,45 \pm 2,29$ & 0,242 \\
\hline \multirow{3}{*}{\multicolumn{2}{|c|}{ Gradus tumora / n (\%) }} & 1 & $7(20,0)$ & $9(25,7)$ & 0,573 \\
\hline & & 2 & $23(65,7)$ & $24(68,6)$ & 0,798 \\
\hline & & 3 & $5(14,3)$ & $2(5,7)$ & 0,234 \\
\hline \multirow{4}{*}{\multicolumn{2}{|c|}{ Tip tumora-IHC / n (\%) }} & 1 & $5(14,3)$ & $12(34,3)$ & 0,053 \\
\hline & & 2 & $23(65,7)$ & $19(54,3)$ & 0,334 \\
\hline & & 3 & $5(14,3)$ & $3(8,6)$ & 0,457 \\
\hline & & 4 & $2(5,7)$ & $1(2,9)$ & 0,566 \\
\hline \multirow{2}{*}{\multicolumn{2}{|c|}{ Estrogen / n (\%) }} & $+(>1 \%)$ & $28(80,0)$ & $31(88,6)$ & \multirow{2}{*}{0,326} \\
\hline & & $-(<1 \%)$ & $7(20,0)$ & $4(11,4)$ & \\
\hline \multirow{2}{*}{\multicolumn{2}{|c|}{ Progesteron / n (\%) }} & $+(>1 \%)$ & $22(62,9)$ & $27(77,1)$ & \multirow{2}{*}{0,198} \\
\hline & & $-(<1 \%)$ & $13(37,1)$ & $8(22,9)$ & \\
\hline \multirow{2}{*}{ HER2 / n (\%) } & & + & $10(28,6)$ & $5(14,3)$ & \multirow{2}{*}{0,148} \\
\hline & & - & $25(71,4)$ & $30(85,7)$ & \\
\hline \multirow{2}{*}{$\begin{array}{l}\text { Ki67 } \\
\text { ekspresija / n (\%) }\end{array}$} & & ( $(\geq 20 \%)$ & $21(60,0)$ & $13(37,1)$ & \multirow{2}{*}{0,057} \\
\hline & & $(<20 \%)$ & $14(40,0)$ & $22(62,9)$ & \\
\hline
\end{tabular}

Objašnjenje - tip tumora: 1 - luminalni A, 2 - luminalni B, 3 - HER2+, 4 - trostruko negativni.

Tablica 7. Korelacije indeksa tjelesne mase (ITM), waist hip ratio (WHR), opsega struka (OS) i dobi s veličinom tumora (VT), statusom estrogenskih receptora (E), statusom progesteronskih receptora (P) i Ki67 ekspresijom. Rezultat povezanosti izražen je kao Pearsonov koeficijent korelacije $(r)$.

\begin{tabular}{|l|c|c|c|c|}
\cline { 2 - 5 } \multicolumn{1}{c|}{} & VT & E & P & Ki67 \\
\hline ITM & 0,11 & 0,21 & 0,32 & $-0,22$ \\
\hline OS & 0,23 & 0,24 & 0,32 & $-0,19$ \\
\hline WHR & 0,13 & 0,14 & 0,18 & $-0,35$ \\
\hline Dob & 0,16 & 0,24 & 0,41 & $-0,07$ \\
\hline
\end{tabular}

\section{RASPRAVA}

Raspodjelom u skupine s obzirom na pridruženi ITM dokazala se statistički značajno veća pojavnost estrogen pozitivnih $(P=0,037)$, progesteron pozitivnih $(P<0,001)$ te luminal $\mathrm{A}$ karcinoma dojke $(P$ $=0,019)$ u skupini prekomjerno uhranjenih (ITM > $25 \mathrm{~kg} / \mathrm{m}^{2}$ ) pacijentica (tablica 4). Nadalje, rezultati ovog istraživanja pokazali su statistički značajno veću učestalost estrogen pozitivnih $(P=0,042)$, progesteron pozitivnih $(P=0,008)$ i luminal A karcinoma dojke $(P=0,042)$, a značajno manju učestalost trostruko negativnih karcinoma $(P=0,014)$ unutar skupine s OS $>80 \mathrm{~cm}$ (tablica 5 ). Naši rezultati u skladu su s izvorima pronađenim u literaturi, primjerice $s$ istraživanjem Whitea i suradnika, $u$ kojem je zamijećena povezanost šireg opsega stru- ka i većeg rizika za razvoj estrogen i progesteron pozitivnih karcinoma dojke $(81-88 \mathrm{~cm}$ vs $\leq 80 \mathrm{~cm}$ : $\mathrm{HR}=1,63[95 \% \mathrm{Cl} 1,36-1,96] ;>88 \mathrm{~cm}$ vs $\leq 80 \mathrm{~cm}$ $\mathrm{HR}=1,53[95 \% \mathrm{Cl} 1,29-1,81])^{10}$.

Podjelom prema WHR-u u ovoj studiji nije pronađena statistički značajna razlika u tumorskim karakteristikama (tablica 6). Sukladno rezultatima ovog istraživanja, Morimoto i suradnici pronašli su povezanost rizika za razvoj karcinoma dojke $s$ vrijednostima OS-a i OB-a, ali ne i za WHR (RR =

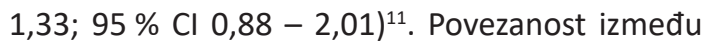
WHR-a i većeg rizika za razvoj karcinoma dojke, neovisno o podtipu, nije pronađena niti u istraživanju Trivers i suradnika ${ }^{12}$. Istraživanje Pacholczak i suradnika dokazalo je povezanost WHR-a s većim rizikom za razvoj karcinoma dojke u premenopauzalnih žena, međutim, ista povezanost nije 
pronađena u postmenopauzalnih žena ${ }^{13}$. White i suradnici u svojoj su studiji dokazali da žene s većim WHR-om imaju općenito veći rizik za razvoj estrogen i progesteron pozitivnih, kao i estrogen $\mathrm{i}$ progesteron negativnih karcinoma dojke u odnosu na one s manjim WHR-om (HR =1,35; $95 \% \mathrm{Cl}$ $1,19-1,54)^{10}$. Povezanost većeg rizika za razvoj karcinoma dojke $s$ većim vrijednostima ITM (OR = 2,94; $95 \% \mathrm{Cl} 1,53-5,68)$, OS (OR = 2,02; $95 \% \mathrm{Cl}$ $1,05-3,91)$ i WHR (OR = 3.64; $95 \% \mathrm{Cl} 1,88-$ $7,05)$ u postmenopauzalnih žena, ali ne i u skupini premenopauzalnih žena, pronađena je $u$ istraživanju Tiana i suradnika ${ }^{14}$. Povezanost OS-a i WHR-a s rizikom za razvoj karcinoma dojke dokazali su i Folsom i suradnici, ali pritom nisu pratili povezanost antropometrijskih parametara s pojedinim podtipovima karcinoma dojke ${ }^{15}$. Međutim, Millikan i suradnici u svojem su istraživanju ustanovili povezanost između većih vrijednosti WHR-a $s$ većim rizikom od razvoja trostruko negativnog karcinoma dojke, te s učestalošću ER i PR pozitivnih karcinoma ${ }^{16}$.

Metaanaliza Chena i suradnika ustvrdila je statistički značajnu povezanost između ITM-a i pojavnosti karcinoma dojke u postmenopauzalnih žena koje prethodno nisu uzimale hormonsku nadomjesnu terapiju ( $\mathrm{R}=1,43 ; 95 \% \mathrm{Cl} 1,21-1,68)$ te u pacijentica $S$ ER pozitivnim karcinomima dojke ( $\mathrm{R}=1,32 ; 95 \% \mathrm{Cl}$ 1,23-1,42). Takvi rezultati podudaraju se s rezultatima ovog istraživanja, gdje su ER pozitivni karcinomi bili statistički značajno češći u skupini prekomjerno uhranjenih pacijentica. U Chenovoj metaanalizi zamijećene su i razlike $u$ povezanosti $s$ obzirom na pridružena geografska područja, tako da je povezanost bila snažnije izražena u Aziji ( $R R=2,10 ; 95 \% \mathrm{Cl}$ 1,64 2,69) i Americi ( $R R=1,29 ; 95 \% \mathrm{Cl} 1,14-1,46) \mathrm{u}$ odnosu na Europu ( $R R=1,19,95 \% \mathrm{Cl}$ 0,98 $1,43)^{17}$. Hui i suradnici pronašli su poveznicu između porasta ITM-a u populaciji istočnoazijskih žena $s$ povećanim rizikom od razvoja luminalnih $(18,5-24,9$ vs < 18,5: OR $=1,58,95 \% \mathrm{Cl} 1,02-$ 2,43 ; $\geq 25$ vs < 18,5: OR = 2,58, $95 \% \mathrm{Cl} 1,60-$ 4,14; $P<0,001)$ i trostruko negativnih karcinoma dojke (OR = 2,96, $95 \% \mathrm{Cl}$ 1,34-6,54; $P<0,001)$. Za podskupinu postmenopauzalnih žena utvrđen je povećani rizik za luminalni tip karcinoma dojke (OR $=1,48 ; 95 \% \mathrm{Cl} 1,08-2,04)$, ali ne i za tro- struko negativni ${ }^{18}$. Slična studija napravljena je i na uzorku europskih žena s invazivnim karcinomom dojke te je također zamijećena povezanost prekomjerne uhranjenosti s pojavnosti luminalnog A tipa karcinoma dojke $(P=0,012)^{19}$. Povećan ITM povezan je s većom količinom masnog tkiva i višom koncentracijom estrogena, čime se može objasniti brži rast ER pozitivnih tumora u pretilih osoba ${ }^{19,20}$. Phipps i suradnici također su dokazali povezanost ITM-a i povišene koncentracije endogenog estrogena u postmenopauzalnih žena ${ }^{21}$.

Raspodjelom u skupine s obzirom na pridruženi indeks tjelesne mase (ITM) i opseg struka (OS) dokazana je statistički značajno veća pojavnost estrogen pozitivnih, progesteron pozitivnih te luminal A karcinoma dojke $u$ skupini prekomjerno uhranjenih (ITM $\left.>25 \mathrm{~kg} / \mathrm{m}^{2}\right)$ pacijentica te u skupini pacijentica $s$ OS $>80 \mathrm{~cm}$.

Zahvaćenost limfnih čvorova jedan je od najvažnijih prognostičkih čimbenika u pacijentica oboljelih od karcinoma dojke. Chung i suradnici došli su do zaključka kako je povezanost ITM-a i statusa hormonskih receptora u dijagnozi karcinoma dojke važan prognostički čimbenik jedino u skupini žena s karcinomom dojke koji je infiltrirao limfne čvorove ${ }^{22}$.

$U$ našem istraživanju dobivena je statistički značajno veća pojavnost estrogen-pozitivnih, progesteron-pozitivnih i luminal A karcinoma dojke te značajno manji broj trostruko negativnih karcinoma dojke s porastom količine masnog tkiva, posebice onog centralne lokalizacije. Ovi su rezultati sukladni istraživanju Phipps i suradnika te Borgquist i suradnika ${ }^{21,23}$. Mehanizmi djelovanja preuhranjenosti i debljine na razvoj karcinoma dojke raznoliki su - od rezistencije inzulina u pretilih žena, preko subkliničke upale, do stanja povišene ekspresije aromataze, enzima koji katalizira konverziju androgena $u$ estrogene ${ }^{24,25}$. Nekoliko istraživanja istaknulo je razliku u ekspresiji tumorskih gena luminalnog A podtipa karcinoma dojke u pretilih, odnosno razliku u stupnju ekspresije gena povezanih s mTOR i p53 signalnim putevima ${ }^{19,26,27}$. U karcinomu dojke dolazi do mutacije i promjene $u$ ekspresiji potonjih gena te aktivacije signalnih puteva, a time $\mathrm{i}$ do promjena $u$ rastu $\mathrm{i}$ diferencijaciji tumorskih stanica. 


\section{ZAKLJUČCI}

Postmenopauzalne žene $\mathrm{s}$ indeksom tjelesne mase $>25 \mathrm{~kg} / \mathrm{m}^{2}$ češće razvijaju karcinom dojke s visokim stupnjem ekspresije estrogenskih i progesteronskih receptora te s niskim stupnjem ekspresije Ki67 i HER2 membranskih receptora. Podatak da s količinom masnog tkiva raste stupanj ekspresije estrogena i progesterona mogao bi se objasniti porastom ekspresije aromataze, enzima koji katalizira konverziju androgena $u$ estrogene.

Izjava o sukobu interesa: autori izjavljuju da ne postoji sukob interesa.

\section{LITERATURA}

1. Ferlay J, Soerjomatarm I, Dikshit R, Eser S, Mathers C, Rebelo $\mathrm{M}$ et al. Cancer incidence and mortality worldwide: sources, methods and major patterns in GLOBOCAN 2012. Int J Cancer 2015;136:359-86.

2. Forouzanfar $\mathrm{MH}$, Foreman KJ, Delossantos $\mathrm{AM}$, Lozano R, Lopez AD, Murray JC et al. Breast and cervical cancer in 187 countries between 1980 and 2010: a systematic analysis. Lancet 2011;378:1461-84.

3. Hrvatski zavod za javno zdravstvo, Registar za rak Republike Hrvatske. Incidencija raka u Hrvatskoj 2014., Bilten 39, Zagreb, 2016.

4. Gompel A, Baber RJ, de Villiers TJ, Huang KE, Santen RJ, Shah D et al. Oncology in midlife and beyond. Climacteric 2013;16:522-35.

5. Ghiasvand R, Adami HO, Harirchi I, Akrami R, Zendehdel $\mathrm{K}$. Higher incidence of premenopausal breast cancer in less developed countries; myth or truth? BMC Cancer 2014;14:343-50.

6. Surakasula A, Nagarjunapu GC, Raghavaiah KV. A comparative study of pre- and post-menopausal breast cancer: Risk factors, presentation, characteristics and management. J Res Pharm Pract 2014;3:12-8.

7. Musić Milanović S, Bukal D. Epidemiologija debljine javnozdravstveni problem. Medicus 2018;27:7-13.

8. Bergström A, Pisani P, Tenet V, Wolk A, Adami HO. Overweight as an avoidable cause of cancer in Europe. Int J Cancer 2001;91:421-30.

9. Harvie M, Hooper L, Howell AH. Central obesity and breast cancer risk: a systematic review. Obes Rev 2003;4:157-73.

10. White AJ, Nichols HB, Bradshaw PT, Sandler DP. Overall and central adiposity and breast cancer risk in the Sister Study. Cancer 2015;121:3700-8.

11. Morimoto LM, White E, Chen Z, Chlebowski RT, Hays J, Kuller L et al. Obesity, body size, and risk of postmenopausal breast cancer: the Women's Health Initiative (United States). Cancer Causes Control 2002;13:741-51.

12. Trivers KF, Lund MJ, Porter PL, Liff JM, Flagg EW, Coates RJ et al. The epidemiology of triple-negative breast cancer, including race. Cancer Causes Control 2009;20: 1071-82.
13. Pacholczak R, Klimek Piotrowska W, Kusmiersz P. Associations of anthropometric measures on breast cancer risk in pre- and postmenopausal women - a case-control study. Journal of Physiological Anthropology 2016;35:7-16.

14. Tian YF, Chu CH, Wu MH, Chang CL, Yang T, Chou YC et al. Anthropometric measures, plasma adiponectin, and breast cancer risk. Endocrine Related Cancer 2007;14:669-77.

15. Folsom AR, Kushi LH, Anderson KE, Mink PJ, Olson JE, Hong $\mathrm{CP}$ et al. Associations of general and abdominal obesity with multiple health outcomes in older women: the Iowa Women's Health Study. Arch Intern Med 2000;160:2117-28.

16. Millikan RC, Newman B, Tse CK, Moorman PG, Conway $\mathrm{K}$, Smith LV et al. Epidemiology of basal-like breast cancer. Breast Cancer Res Treat 2008;109:123-39.

17. Chen Y, Liu L, Zhou Q, Imam MU, Cai J, Wang Y et al. Body mass index had different effects on premenopausal and postmenopausal breast cancer risks: a dose-response meta-analysis with 3,318,796 subjects from 31 cohort studies. BMC Public Health 2017;17:936-46.

18. Hui L, Xuezheng S, Erline M, Qiong W, Ping T, Li L et al. $\mathrm{BMI}$, reproductive factors, and breast cancer molecular subtypes: A case-control study and meta-analysis. Journal of Epidemiology 2017;27:143-51.

19. Hankó Bauer O, Georgescu R, Coros MF, Boros M, Barsan I, Stolnicu S. Correlation between obesity and prognostic/predictive parameters with emphasis on the importance of lymph node metastases in patients with invasive breast carcinoma. Pol J Pathol 2017;68:33-9.

20. Neuhouser ML, Aragaki AK, Prentice RL, Manson JE, Chlebowski R, Carty $\mathrm{CL}$ et al. Overweight, Obesity and Postmenopausal Invasive Breast Cancer Risk. JAMA Oncol 2015;1:611-21.

21. Phipps Al, Malone KE, Porter PL, Daling JR, Li Cl. Body Size and Risk of Luminal, HER2-Overexpressing, and Triple-Negative Breast Cancer in Postmenopausal Women. Cancer Epidemiol Biomarkers Prev 2008;17:2078-86.

22. Chung IY, Lee JW, Lee JS, Park YR, Min YH, Lee $Y$ et al. Interaction between body mass index and hormone-receptor status as a prognostic factor in lymph-node-positive breast cancer. PLoS One 2017; Forthcoming.

23. Borgquist S, Jirström K, Anagnostaki L, Manjer J, Landberg G. Anthropometric factors in relation to different tumor biological subgroups of postmenopausal breast cancer. Int J Cancer 2009;124:402-11.

24. Simone V, D’Avenia M, Arqentiero A, Felici C, Rizzo FM, De Pergola $G$ et al. Obesity and Breast Cancer: Molecular Inerconnections and Potential Clinical Applications. Oncologist 2016;21:404-17.

25. Morris PG, Hudis CA, Giri D, Morrow M, Falcone DJ, Zhou $\mathrm{XK}$ et al. Inflammation and increased aromatase expression occur in the breast tissue of obese women with breast cancer. Cancer Prev Res (Phila) 2011;4:1021-9.

26. Toro AL, Costantino NS, Shriver CD, Ellsworth DL, Ellsworth RE. Effect of obesity on molecular characteristics of invasive breast tumors: gene expression analysis in a large cohort of female patients. BMC Obesity 2016;3:22-30.

27. Fuentes Matei E, Velazquez Torres G, Phan L, Zhang F, Chou PC, Shin JH et al. Effects of obesity on transcriptomic changes and cancer hallmarks in estrogen receptorpositive breast cancer. J Natl Cancer Inst 2014;106:1-12. 